\title{
PENINGKATAN KEMAMPUAN PEMILIHAN KARIR MELALUI MODEL LAYANAN INFORMASI BERBASIS WHATSAPP GROUP DI SEKOLAH
}

\author{
MAE ENDANG IRIASTUTI \\ SMK Negeri 1 Kalasan \\ e-mail: maeprambanan@gmail.com
}

\begin{abstract}
ABSTRAK
Kemampuan pemilihan karir merupakan kemampuan individu dalam menyelesaikan tugas perkembangan karir, yang sesuai dengan tahap perkembangannya. Pembahasan tentang kemampuan pemilihan karir dilatarbelakangi oleh masalah, masih banyaknya peserta didik yang bingung dalam menentukan karirnya setelah lulus SMK. Pada masa pandemic Covid-19 seperti saat ini, konsultasi daring adalah salah satu alternative. Kecenderungan peserta didik saat ini lebih menyukai media sosial secara online sedangkan WhatsApp adalah aplikasi yang paling popular. Penelitian tindakan bimbingan konseling ini bertujuan guna mengetahui peningkatkan kemampuan pemilihan karir melalui layanan informasi berbasis WhatsApp Group untuk siswa kelas XII SMK Negeri 1 Kalasan tahun pelajaran 2020-2021. Penentuan sampel menggunakan teknik simple random sampling. Subjek penelitian berjumlah 31 peserta didik. Desain penelitian dengan model Kemmis dan McTaggart dengan 4 tahapan. Hasil penelitian menunjukkan bahwa skor kemampuan pemilihan karir dan pemanfaatan WhatsApp Group pada siklus I didapat jumlah skor 129,25 dengan rata-rata 83,39\%, sedangkan pada siklus II didapat jumlah skor 135,2 dengan rata-rata 87,25\%, terdapat peningkatan sebesar 3,86\%. Hal ini dapat dibuktikan juga pada peserta didik bahwa motivasinya meningkat, mempunyai konsep diri positif, pemahaman perguruan tinggi dan dunia kerja meningkat yang menjadikan kemampuan pemilihan karir meningkat. Sehingga penelitian ini dapat disimpulkan bahwa hipotesis diterima yakni adanya peningkatan kemampuan pengambilan keputusan karir melalui layanan informasi berbasis WhatsApp Group pada siswa SMK Negeri 1 Kalasan tahun pelajaran 2020-2021.
\end{abstract}

Kata Kunci : Layanan Informasi, Whatsapp Group, Pemilihan Karir.

\section{ABSTRACT}

The ability to choose a career is an individual's ability to complete career development tasks, which are in accordance with the stage of development. The discussion about the ability to choose a career is motivated by the problem, there are still many students who are confused in determining their career after graduating from SMK. During the current Covid-19 pandemic, online consultation is an alternative. The tendency of students today to prefer online social media while WhatsApp is the most popular application. This counseling guidance action research aims to determine the improvement of career choice skills through WhatsApp Groupbased information services for class XII students of SMK Negeri 1 Kalasan for the 2020-2021 school year. Determination of the sample using simple random sampling technique. The research subjects were 31 students. Research design using Kemmis and McTaggart models with 4 stages. The results showed that the score of the ability to choose a career and use WhatsApp Group in the first cycle obtained a total score of 129.25 with an average of $83.39 \%$, while in the second cycle the total score was 135.2 with an average of $87.25 \%$. an increase of $3.86 \%$. This can also be proven to students that their motivation increases, they have a positive selfconcept, their understanding of higher education and the world of work increases which makes their ability to choose careers increase. So that this research can be concluded that the hypothesis is accepted, namely an increase in career decision-making abilities through WhatsApp Group-based information services for students of SMK Negeri 1 Kalasan for the academic year 2020-2021.

Keywords: Information Services, Whatsapp Group, Career Selection. 


\section{PENDAHULUAN}

Perkembangan tehnologi dan informasi pada era saat ini harus diakui bahwa hal tersebut sangat mempengaruhi masyarakat, terutama setelah internet membudaya di masyarakat. Berbagai kemudahan didapat setelah mengakses internet. Saat ini internet telah menjadi kebutuhan pokok masyarakat untuk berbagai aspek. Baik itu aspek pendidikan, aspek kebudayaan, aspek ekonomi, maupun aspek sosial dan lain sebagainya. Tehnologi dalam pendidikan merupakan sarana yang dapat digunakan untuk menyajikan informasi dalam pendidikan dan latihan. Pendidikan sebagai salah satu bidang yang memanfaatkan tehnologi informasi. Penguasaan tehnologi informasi merupakan nilai tambah bagi seorang konselor dalam memberikan pelayanan bimbingan konseling. Pelayanan yang cenderung dilakukan secara konvensional dan tidak berkembang sehingga membosankan bagi kalangan masyarakat yang memang sudah mengenal tehnologi informasi. Dari kondisi tersebut maka seorang konselor perlu memahami peranan tehnologi informasi dalam bimbingan konseling sehingga pelayanan bimbingan konseling dapat dilaksanakan sesuai dengan kebutuhan peserta didik dan tentunya mendasarkan kepada asas kebutuhan dan kekinian.

Informasi akan Karir merupakan kebutuhan yang sangat diperlukan oleh peserta didik khususnya kelas XII, akan tetapi kebutuhan informasi tersebut dapat menjadi masalah ketika tidak dapat terpenuhi. Peserta didik selalu membutuhkan sumber informasi untuk pemenuhan akan kebutuhannya, terutama di bidang karir untuk siswa kelas XII, dimana mereka dituntut untuk kesiapan karir yaitu pilihan jabatan atau studi lanjut setelah tamat sekolah sehingga memiliki kemampuan dalam mengambil putusan yang tepat.

Pengambilan keputusan setelah lulus SMK maupun pilihan jabatan tidaklah mudah. Terdapat beberapa hal yang perlu dipertimbangkan dalam studi lanjut di Perguruan Tinggi atau pilihan jabatan. Menurut Yusuf (2011) faktor yang perlu dipertimbangkan adalah minat, kebutuhan, kapasitas, nilai dan kesempatan, maka peserta didik perlu memiliki gambaran yang tepat tentang jabatan dan Perguruan Tinggi. Dalam penelitian Peningkatan Kemampuan Pemilihan Karir Melalui Model Layanan Informasi Berbasis Whatsapp Group ini, peneliti mengambil satu permasalahan yaitu 'Pemilihan Karir'. Munandar (2004) menyatakan beberapa masalah pokok adalah susahnya siswa mencari sekolah studi lanjut untuk segala jenjang dan sulitnya orang mencari pekerjaan. Hal ini disebabkan oleh kurangnya wawasan, pengetahuan dan informasi mengenahi Karir.

Berdasarkan hasil wawancara pada beberapa peserta didik kelas XII di SMK Negeri 1 Kalasan, bahwa mereka masih kurang memahami tentang informasi Karir, karena informasi yang didapat hanya tergantung pada kakak kelas saja, mereka belum ada kesadaran untuk mencari informasi dari sumber lain. Pada masa pandemic Covid-19 seperti saat ini, konsultasi daring adalah salah satu alternatif yang dapat dilakukan. Sementara peserta didik yang lain ada sebagian yang belum mempunyai tujuan dan sebagian lagi ingin langsung ke dunia kerja.

Konsultasi daring merupakan kegiatan yang memanfaatkan jaringan internet, LAN, WAN sebagai metode interaksi, penyampaian materi, dan diskusi. Arif Mustofa (2020) menyatakan bahwa media pembelajaran daring yang banyak dan mudah digunakan adalah aplikasi WhatsApp. Demikian juga, 66 peserta didik. tersebut, dalam berkonsultasi menggunakan whatsapp pribadi. Karena pertanyaan dan kendala yang disampaikan para peserta didik. hampir sama, maka untuk menghemat waktu, dan supaya informasi lebih merata, penulis membuat WhatsApp Group dengan tujuan memudahkan komunikasi, memberikan informasi yang merata dan sebagai ajang diskusi tentang masalah yang menjadi kendala peserta didik yaitu masalah karir.

Berdasarkan penelitian yang dilakukan oleh Indah Wijaya dan Wiwik Novianti (2019) Menulis Pustaka cukup tinggi/ altif yang dibuktikan dengan terbitnya 6 judul buku bunga rampai. Penelitian Tarsudi (2016) bahwa media layanan informasi karir berbasis Web memiliki kelayakan dengan kategori sangat tinggi dalam penggunaannya, dan dijadikan media yang membantu layanan informasi karir. Penelitian Nur Lia Pangestika (2018), bahwa media social WhatsApp Group berpengaruh terhadap penyebaran informasi pembelajaran sebesar 38,5 \%. 
Berdasarkan beberapa penelitian diatas dapat disimpulkan bahwa pemanfatan dan penggunaan WhatsApp kelayakannya sangat tinggi, dan penggunaan WhatsApp berpengaruh terhadap penyebaran informasi pembelajaran. Menilik pada permasalahan yang berkembang di atas, Penelitian Peningkatan Model layanan informasi berbasis WhatsApp Group ini memfokuskan pada Peningkatan Kemampuan Pemilihan Karir Melalui Model Layanan Informasi Berbasis Whatsapp Group Untuk Siswa Kelas XII SMK Negeri I Kalasan Tahun Pelajaran 2020-2021

\section{METODE PENELITIAN}

Penelitian tindakan kelas ini menggunakan model Kemmis dan McTaggart. Gambaran model Penelitian Tindakan Kelas Kemmis dan McTaggart dapat dilihat pada gambar 1.

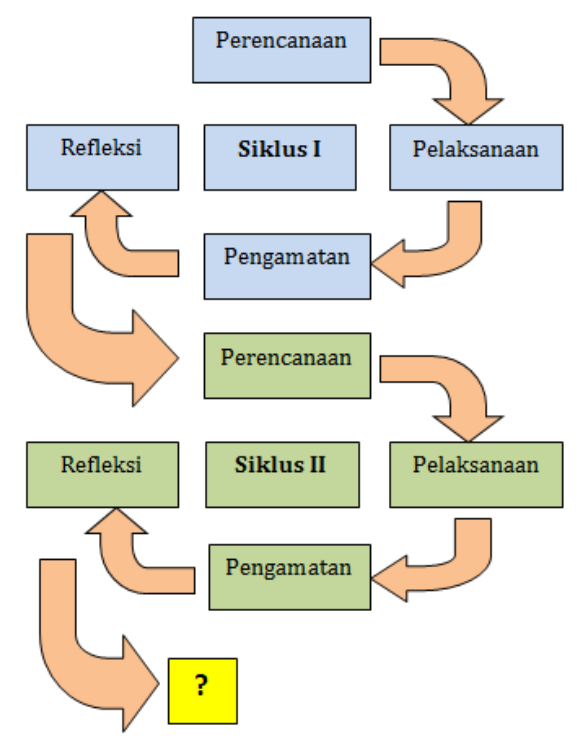

\section{Gambar 1 : Model Dasar Siklus Penelitian Tindakan Kelas Kemmis dan McTaggart (Kasbolah, 1993)}

Identifikasi

Penelitian Tindakan ini dilakukan di SMK Negeri 1 Kalasan yang beralamat di Dusun Tamanmartani, Kapanewon Kalasan, Kabupaten Sleman, Daerah Istimewa Yogyakarta dengan secara daring (dalam jaringan) atau online. Waktu kegiatan pelayanan dilaksanakan pada tanggal 4 Februari sampai 18 Maret 2021. Adapun jadwal pelaksanaan kegiatan dalam tabel 1.

Tabel 1: Jadwal Kegiatan.

\begin{tabular}{|c|l|l|}
\hline No & \multicolumn{1}{|c|}{ Tanggal } & \multicolumn{1}{c|}{ Kegiatan } \\
\hline 1 & 4 sd 6 Feb 2021 & $\begin{array}{l}\text { Pertemuan 1, pembuatan instrumen, peserta didik } \\
\text { bergabung dalam Whatsapp Group }\end{array}$ \\
\hline 2 & 8 dan 9 Feb 2021 & $\begin{array}{l}\text { Pelaksanaan Siklus I Pertemuan ke 2 } \\
\text { *diskusi. *evaluasi proses }\end{array}$ \\
\hline 3 & 10 sd 17 Feb 2021 & $\begin{array}{l}\text { Pertemuan ke 3. } \\
\text { *Presentasi hasil diskusi*evaluasi hasil*refleksi } \\
\text { siklus 1 }\end{array}$ \\
\hline 4 & 18 sd 24 Feb 2021 & $\begin{array}{l}\text { Pelaksanaan Siklus II Pertemuan ke 1 } \\
\text { *diskusi. *evaluasi proses }\end{array}$ \\
\hline 5 & 25 sd 28 Maret 2021 & $\begin{array}{l}\text { Pelaksanaan Siklus II Pertemuan ke 2 } \\
\text { *Presentasi hasil diskusi* }\end{array}$ \\
\hline 6 & 29 Feb sd 18 Maret 2021 & Pelaksanaan Siklus II Pertemuan ke 3 \\
\hline
\end{tabular}


Vol. 2 No. 1 Februari 2022, e-ISSN : 2797-0140 | p-ISSN : 2797-0590

\begin{tabular}{|l|l|l|}
\hline & $\begin{array}{l}* \text { membuat simpulan hasil. *evaluasi } \\
\text { hasil*Pelaporan. }\end{array}$ \\
\hline
\end{tabular}

Subjek penelitian siswa SMK Negei 1 Kalasan yang dilibatkan mulai dari studi pendahuluan sampai tindakan layanan sedangkan Guru bimbingan konseling sebagai kolaborator dalam penelitian. Populasi penelitian sejumlah 350 peserta didik kelas XII SMK Negeri 1 Kalasan. Pemilihan sample ditentukan dengan menggunakan teknik sample random sampling yang mengedepankan prinsip bahwa semua individu memiliki kesempatan yang sama. Sample random sampling adalah teknik pengambilan sample dari anggota populasi yang dilakukan secara acak tanpa memperhatikan strata yang ada dalam populasi (Sugiyono,2009). Dalam penelitian ini yang menjadi sampel adalah 31 peserta didik, kelas XII dimana masingmasing jurusan diwakili dan merupakan anggota dari WhatsApp Group.

\section{HASIL DAN PEMBAHASAN}

Hasil.

Penelitian Tindakan Bimbingan Konseling dilakukan di kelas XII SMK Negeri 1 Kalasan tahun pelajaran 2020-2021, dilaksanakan dalam 2 siklus dengan 4 empat tahapan McTaggart yakni 1) tahap perencanaan, 2) tahap tindakan dan 3) observasi serta 4) tahap refleksi dengan 6 kali tindakan.

Siklus 1. Hasil analisa kebutuhan menunjukkan bahwa, terdapat 66 perserta didik yang memerlukan layanan informasi pemilihan keputusan setelah lulus SMK secara intensif. Hasil uji kelayakan materi, yang dinyatakan bahwa materi sangat layak untuk digunakan dalam layanan informasi berbasis WhatsApp Group dengan skor total 84,93\% kategori sangat layak. Namun terdapat beberapa revisi dari validator yaitu penggunaan model layanan berbasis WhatsApp Group dilaksanaan sejak kelas XI, perlunya tambahan materi layanan informasi. Hasil analisa rumusan tujuan adalah 1) dapat lebih memahami dan memudahkan dalam menentukan pilihan, 2) saling berbagi informasi dan diskusi, 3) dapat memanfatkan informasi kapanpun dan dimanapun peserta didik belajar. Berdasarkan hasil analisis Penilaian Layanan Segera (Laiseg), dapat disimpulkan bahwa Model layanan informasi pemilihan keputusan setelah lulus SMK berbasis WhatsApp Group untuk siswa kelas XII SMK Negeri 1 kalasan, dapat memberikan sumbangan terhadap pemahaman pemilihan keputusan setelah lulus SMK pada seluruh peserta, sebagian besar peserta merasa senang, lega dan terbantu, serta berani mengambil keputusan. Adanya masukan bahwa layanan ini diadakan setiap tahun, dan dilengkapi dengan layanan jabatan. Hasil Observasi Keefektifan Kegiatan Layanan Informasi dari tiga kali pertemuan dengan objek yang diamati adalah Fasilitas pendukung aplikasi, Penggunaan WhatsApp Gruop, Keaktifan peserta didik, serta Pelaksanaan layanan mendapatkan rata-rata 69,80 \% dengan kriteria efektif. Hasil Skor Angket kemampuan Pemilihan Karir dan Pemanfatan Whats App Group mendapatkan rata-rata 83,39 dengan kriteria sangat efektif.

Berdasarkan hasil observasi terhadap kegiatan layanan informasi berbasis WhatsApp Group pada siklus 1 oleh dua observer serta hasil angket peserta didik, selanjutnya peneliti mengadakan refleksi dengan hasil sebagai berikut : 
Hasil Refleksi Siklus I

1. Terdapat beberapa peserta didik

2. Informasi siswa kurang lengkap

3. Siswa belum mampu memahami

4. Beberapa peserta didik belum potensi dirinya.

5. Beberapa peserta didik merasa belum puas dengan pelaksanaan
Rencana Perbaikan

1. Pembimbing lebih aktif memotivasi belum aktif mengikuti kegiatan peserta didik untuk mengikuti layanan informasi studi lanjut layanan informasi. pada WhatsApp Group

2. Penambahan materi pada RPL

3. Memberikan penguatan peserta potensi dirinya. didik untuk semakin memahami. dapat memberikan informasi pada orang lain

4. Memberikan pemahaman pada orang lain peserta didik tentang manfaat

5. Pelaksanaan layanan dilanjutkan layanan informasi yang sudah dengan siklus II berjalan 2 kali.

\section{Gambar 2 : Hasil Refleksi siklus I dan rencana perbaikan siklus II}

Siklus 2. Berdasarkan hasil analisis Penilaian Layanan Segera (Laiseg) pada siklus II pertemuan pertama dapat disimpulkan bahwa Model layanan informasi pemilihan keputusan setelah lulus SMK berbasis WhatsApp Group untuk siswa kelas XII SMK Negeri 1 kalasan dengan materi mengenal dunia perguruan tinggi dan meningkatkan motivasi, dapat memberikan sumbangan pemahaman pemilihan keputusan setelah lulus SMK pada seluruh peserta didik. Pada pertemuan kedua Hasil Observasi Keefektifan Kegiatan Layanan pada siklus II, mendapatkan skor rata-rata 85,42\% kriteria sangat efektif. Hasil Observasi Kegiatan Layanan Informasi Siklus I dan Siklus II adalah sebagai berikut dalam tabel 2.

Tabel 2 : Hasil Observasi Kegiatan Layanan Informasi Siklus I dan Siklus II

\begin{tabular}{|c|c|c|c|c|}
\hline \multirow{2}{*}{ Objek yang diamati } & \multicolumn{2}{|c|}{ Siklus I } & \multicolumn{2}{c|}{ Siklus II } \\
\cline { 2 - 5 } & Rata2 & Kriteria & Rata2 & Kriteria \\
\hline Fasilitas pendukung aplikasi & $83,33 \%$ & Sangat efektif & $83,34 \%$ & $\begin{array}{c}\text { Sangat } \\
\text { efektif }\end{array}$ \\
\hline Penggunaan WhatsApp Gruop & $66,67 \%$ & efektif & $100 \%$ & $\begin{array}{c}\text { Sangat } \\
\text { efektif }\end{array}$ \\
\hline Keaktifan peserta didik & $66,67 \%$ & efektif & $83,34 \%$ & $\begin{array}{l}\text { Sangat } \\
\text { efektif }\end{array}$ \\
\hline Pelaksanaan layanan. & $62,50 \%$ & efektif & $75 \%$ & Efektif \\
\hline Skor rata-rata & $\mathbf{6 9 , 8 0 \%}$ & efektif & $\mathbf{8 5 , 4 2 \%}$ & $\begin{array}{c}\text { Sangat } \\
\text { efektif }\end{array}$ \\
\hline
\end{tabular}


Vol. 2 No. 1 Februari 2022, e-ISSN : 2797-0140 | p-ISSN : 2797-0590

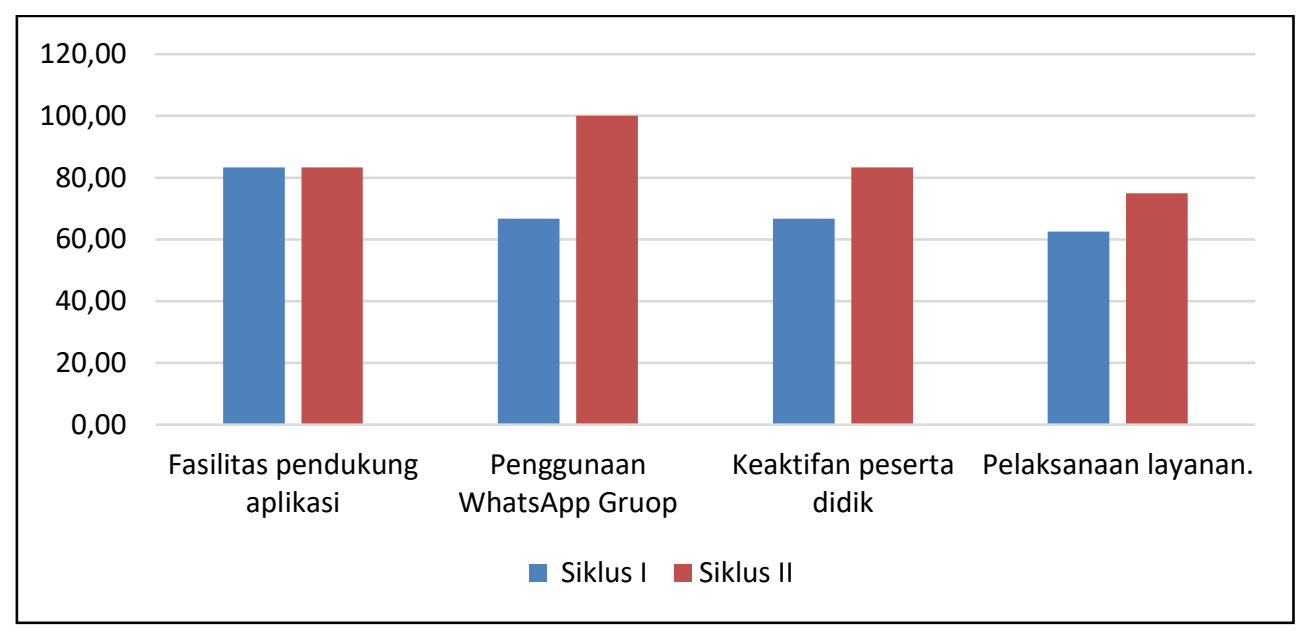

Gambar 3. Grafik 1 Hasil Observasi Kegiatan Layanan Informasi Siklus I dan Siklus I

Tabel 3 : Hasil Penilaian Kemampuan Pemilihan Karir Dan Pemanfaatan Whatsapp Gruop pada Siklus I dan Siklus II

\begin{tabular}{|c|c|c|c|c|c|c|c|}
\hline \multirow{2}{*}{ No } & \multirow{2}{*}{ Diskripsi } & \multicolumn{2}{|c|}{ Siklus I } & \multirow{2}{*}{ Kategori } & \multicolumn{2}{|c|}{ Siklus II } & \multirow[t]{2}{*}{ Kategori } \\
\hline & & Skor & $\%$ & & Skor & $\%$ & \\
\hline 1 & $\begin{array}{l}\text { Kesadaran akan } \\
\text { pentingnya } \\
\text { menentukan } \\
\text { pilihan }\end{array}$ & 138,80 & 89,52 & $\begin{array}{l}\text { sangat } \\
\text { efektif }\end{array}$ & 142 & 91,61 & $\begin{array}{l}\text { sangat } \\
\text { efektif }\end{array}$ \\
\hline 2 & $\begin{array}{l}\text { Mampu } \\
\text { memahami } \\
\text { potensi diri. }\end{array}$ & 119 & 76,77 & efektif & 127 & 81,94 & $\begin{array}{l}\text { Sangat } \\
\text { efektif }\end{array}$ \\
\hline 3 & $\begin{array}{l}\text { Memahami } \\
\text { lingkungan pilihan }\end{array}$ & 141,70 & 90,75 & $\begin{array}{l}\text { sangat } \\
\text { efektif }\end{array}$ & 136,7 & 90,54 & $\begin{array}{l}\text { sangat } \\
\text { efektif }\end{array}$ \\
\hline 4 & $\begin{array}{l}\text { Memahami } \\
\text { lingkungan pilihan } \\
\text { secara rinci. }\end{array}$ & 129,5 & 83,55 & $\begin{array}{l}\text { sangat } \\
\text { efektif }\end{array}$ & 143 & 92,26 & $\begin{array}{l}\text { sangat } \\
\text { efektif }\end{array}$ \\
\hline 5 & $\begin{array}{l}\text { Pengambilan } \\
\text { keputusan }\end{array}$ & 132 & 85,16 & $\begin{array}{l}\text { sangat } \\
\text { efektif }\end{array}$ & 134,3 & 86,61 & $\begin{array}{l}\text { sangat } \\
\text { efektif }\end{array}$ \\
\hline 6 & $\begin{array}{l}\text { Yakin terhadap } \\
\text { keputusan }\end{array}$ & 128,6 & 83,61 & efektif & 131,8 & 84,13 & $\begin{array}{l}\text { sangat } \\
\text { efektif }\end{array}$ \\
\hline 7 & Partisipasi & 138,3 & 89,25 & $\begin{array}{l}\text { sangat } \\
\text { efektif }\end{array}$ & 138,3 & 89,25 & $\begin{array}{l}\text { sangat } \\
\text { efektif }\end{array}$ \\
\hline 8 & Manfaat & 146 & 94,19 & $\begin{array}{l}\text { sangat } \\
\text { efektif }\end{array}$ & 146 & 94,19 & $\begin{array}{l}\text { sangat } \\
\text { efektif }\end{array}$ \\
\hline 9 & $\begin{array}{l}\text { Memberikan } \\
\text { Informasi }\end{array}$ & 100 & 64,52 & Efektif & 122 & 78,71 & Efektif \\
\hline 10 & $\begin{array}{l}\text { Menerima } \\
\text { Informasi }\end{array}$ & 131 & 84,52 & $\begin{array}{l}\text { sangat } \\
\text { efektif }\end{array}$ & 133 & 85,81 & $\begin{array}{l}\text { sangat } \\
\text { efektif }\end{array}$ \\
\hline 11 & $\begin{array}{l}\text { Memecahkan } \\
\text { masalah }\end{array}$ & 133,60 & 86,19 & $\begin{array}{l}\text { sangat } \\
\text { efektif }\end{array}$ & 132,8 & 85,68 & $\begin{array}{l}\text { sangat } \\
\text { efektif }\end{array}$ \\
\hline 12 & Yang diharapkan & 144,60 & 93,29 & $\begin{array}{l}\text { sangat } \\
\text { efektif }\end{array}$ & 144,4 & 93,16 & $\begin{array}{l}\text { sangat } \\
\text { efektif }\end{array}$ \\
\hline 13 & Yang dirasakan & 97,25 & 62,74 & efektif & 126,3 & 80,32 & $\begin{array}{l}\text { Sangat } \\
\text { efektif }\end{array}$ \\
\hline & Skor Rata-rata & 129,25 & 83,39 & efektif & 135,20 & 87,25 & $\begin{array}{l}\text { Sangat } \\
\text { efektif }\end{array}$ \\
\hline
\end{tabular}




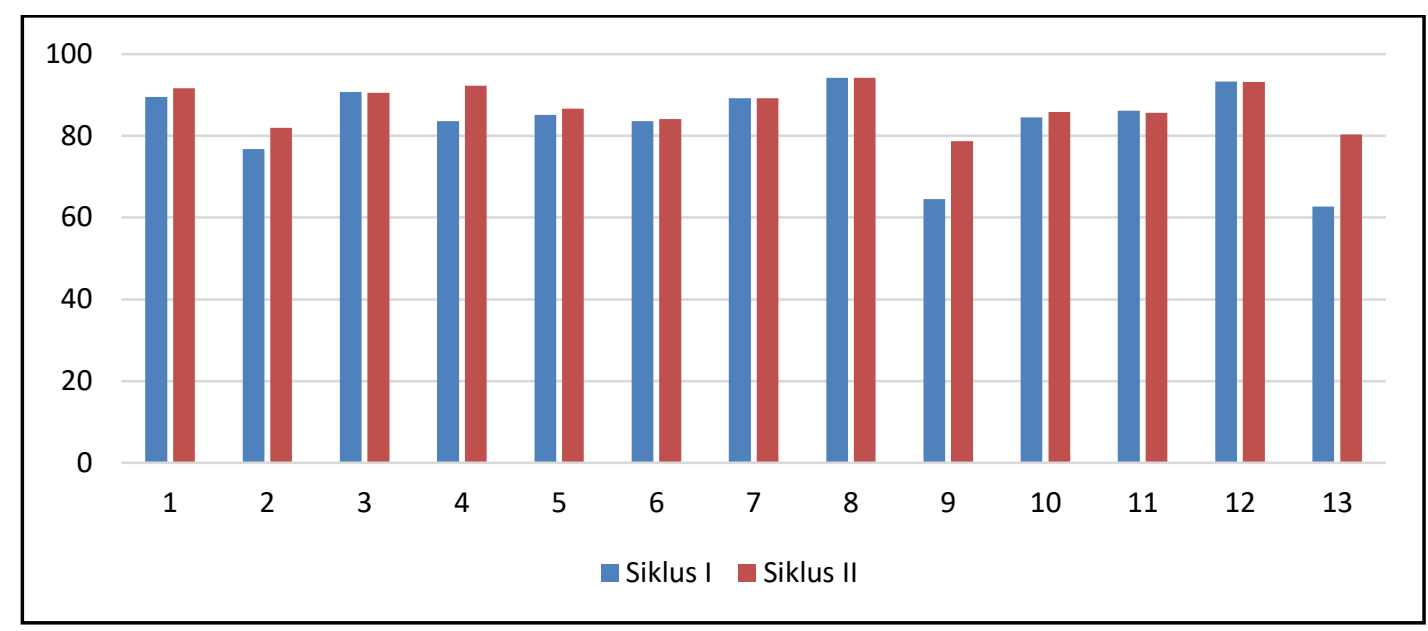

Gambar 4. Grafik Hasil Penilaian Instrumen Kemampuan Pemilihan Karir Dan Pemanfaatan Whatsapp Gruop pada Siklus I dan Siklus II.

Dari hasil penilaian respon peserta didik terhadap pelaksanaan layanan informasi berbasis WhatsApp Group pada siklus I dan siklus II, dapat dilihat bahwa terdapat peningkatan skor pada beberapa aspek diantaranya : 1) Aspek Kemampuan memahami potensi diri, siklus I mendapat skor 67,77 kategori 'efektif', siklus II meningkat menjadi 81,94 kategori 'sangat efektif'. 2) Aspek Kemampuan memahami lingkungan pilihan secara rinci, siklus I mendapat skor 83,55 kategori 'sangat efektif', siklus II meningkat menjadi 92,26 kategori 'angat efektif', 3) Sedangkan pada aspek Peserta didik mampu memberikan Informasi, siklus I mendapat skor 64,52 kategori 'efektif', siklus II meningkat menjadi 78,71 kategori 'efektif'. 4) Pada aspek yang dirasakan peserta didik setelah mengikuti layanan, siklus I mendapat skor 62,74 kategori 'efektif', siklus II meningkat menjadi 80,32 kategori 'sangat efektif'. Hal ini dapat diartikan bahwa layanan informasi pada siklus II terdapat peningkatan hasil dibandingkan dengan layanan informasi pada siklus I.

Berdasarkan hasil observasi terhadap kegiatan layanan informasi berbasis WhatsApp Group pada siklus II oleh dua observer serta hasil angket peserta didik adalah sebagai berikut : Hasil yang diperoleh menunjukkan keaktifan peserta didik siklus II lebih baik dibandingkan dengan keaktifan pada siklus I. Penemuan masalah dalam tindakan yakni permasalahan yang berasal dari pembimbing sendiri maupun dari peserta didik, sudah dapat diatasi. Adapun permasalahan yang muncul dari peserta didik berasal dari peserta didik yang partisipasinya rendah dikarenakan memang peserta didik tersebut mempunyai masalah diluar sekolah dan berkepribadian pendiam.

Melihat beberapa kriteria di atas menunjukkan bahwa secara keseluruhan, mulai dari pra siklus, siklus I serta siklus II, telah terlihat peningkatan dalam hasil maupun proses layanan, maka diputuskan bahwa tindakan penelitian bimbingan konseling ini untuk mengakhiri pada siklus II.

\section{Pembahasan}

Salah satu factor penentu keberhasilan proses layanan informasi adalah kemampuan pembimbing dalam mengelola pelayanan tersebut. Menurut Gunawan (1987), layanan informasi karir dikatakan berhasil jika peserta didik :1) mudah dalam penyesuaian diri, 2) dapat memahami arah pilihan sesuai dengan bakat, minat serta potensi yang sesuai dengan citacitanya, 3) dapat menentukan kelajutan setelahnya. Hasil penelitian tindakan bimbingan konseling dengan judul Peningkatan Kemampuan Pemilihan Karir Melalui Model Layanan Informasi Berbasis WhatsApp Group Untuk Siswa Kelas XII SMK Negeri 1 Kalasan Tahun Pelajaran 2020-2021, menunjukkan bahwa adanya peningkatan kemampuan pengambilan keputusan karir melalui layanan informasi berbasis WhatsApp Group. Menurut Prayitno \& Amti (2008), layanan informasi merupakan perwujudan dari fungsi pemahaman layanan bimbingan dan konseling yang dapat menunjang pelaksanaan fungsi bimbingan konseling 
lainnya dalam kaitan antara masalah orientasi dan informasi pada permasalahan individu. Penelitian Nararya (2016), dengan hasil rata-rata skor sebelum diberi perlakuan adalah 72,15 dan setelah diberi perlakuan meningkat sebesar 87,95. Peningkatan terjadi pada semua indikator pemahaman dunia perguruan tinggi. Ahmad Nafi (2020), peningkatan kematangan karir siswa sebelum dan sesudah diberikan perlakukan sebesar 14,4\%. Uji $t$ menunjukkan t-hitung $>\mathrm{t}$-tabel yaitu $10,088>2,056$. Kematangan karir berbasarkan uji $\mathrm{N}$-gain diperoleh nilai 0,44 pada kategori sedang.

Penelitian tindakan bimbingan konseling ini terdiri dari 2 siklus, dan tiap siklus terdiri dari 3 tindakan. Penelitian tindakan dimulai pada tanggal 4 Februari sampai tanggal 18 Maret 2021. Penelitian didahului dengan wawancara dan chatting pribadi terhadap beberapa peserta didik. Peningkatan kemampuan pengambilan keputusan dapat dilihat melalui hasil observasi dan skor hasil angket respon peserta didik. Hasil observasi dan hasil angket respon peserta didik menjadi data kualitatif yang akan mendukung perolehan data kuantitatif. Berdasar hasil observasi dan skor hasil angket respon peserta didik yang diperoleh, menunjukkan bahwa peserta didik aktif memberi komentar dan merespon serta yakin terhadap arah pilihannya. Peningkatan kemampuan pengambilan keputusan juga dapat dilihat melalui data kuantitaf yang diperoleh dari hasil skala kemampuan pengambilan keputusan oleh peserta didik pada siklus I dan siklus II. Skala Peningkatan kemampuan pengambilan keputusan diberikan kepada peserta didik pada siklus I dan siklus II.

Berdasar skala Peningkatan kemampuan pengambilan keputusan didapat skor pada siklus I diperoleh skor kemampuan pengambilan keputusan sebesar rata-rata 83,39, sedangkan pada siklus II meningkat menjadi 87,25, terjadi peningkatan sebesar 3,86\%. Peningkatan tersebut merupakan hasil perbaikan dari refleksi pada siklus I. Pada peningkatan kemampuan memahami potensi diri, kemampuan memahami lingkungan pilihan secara rinci, kemampuan memberikan Informasi dan yang dirasakan peserta didik setelah mengikuti layanan tentu saja dipengaruhi oleh factor kemampuan pembimbing dalam memberikan layanan dan perbaikan pada Rencana Pelaksanaan Layanannya (RPL). Hal ini dapat diartikan bahwa layanan informasi berbasis WhatsApp Group pada siklus II terdapat peningkatan hasil dibandingkan dengan layanan informasi pada siklus I.

Dengan diterapkannya model layanan informasi berbasis WhatsApp Group ini menunjukkan upaya guru bimbingan konseling memaksimalkan pelaksanaan layanan untuk memberikan pemahaman dan kematangan karier peserta didik yang sesuai dengan Standar Kompetensi Kemandirian Peserta Didik dalam Tugas Perkembangan mengenal kemampuan bakat, minat, serta arah kecenderungan karir.

Penelitian memperoleh hasil bahwa adanya peningkatan skor skala kemampuan pengambilan keputusan. Peningkatan skor kemampuan pengambilan keputusan karir dapat dilihat melalui rata-rata skor respon peserta didik pada siklus I dan siklus II. Pada siklus I didapat jumlah skor 129,25 dengan rata-rata 83,39, sedangkan pada siklus II didapat jumlah skor 135,2 dengan rata-rata 87,25, terdapat peningkatan 3,86. Hasil penelitian ini membuktikan bahwa hipotesis diterima yakni adanya peningkatan kemampuan pengambilan keputusan karir melalui layanan informasi berbasis WhatsApp Group pada siswa SMK Negeri 1 Kalasan tahun pelajaran 2020-2021.

\section{KESIMPULAN}

Penelitian tindakan bimbingan konseling pada peserta didik kelas XII SMK Negeri 1 Kalasan tahun pelajaran 2020-2021 dilaksanakan dalam 2 siklus dengan 6 kali tindakan. Penelitian ini menggunakan model Kemmis dan McTaggart. Sampel diambil menggunakan tehnik acak yang mewakili semua jurrusan. Hasil memperlihatkan bahwa terdapat Peningkatan skor kemampuan pengambilan keputusan karir. Hal ini dapat dilihat melalui rata-rata skor angket pengukuran kemampuan pengambilan keputusan karir dan pemanfataan whatsapp gruop pada siklus I dan siklus II. Pada siklus I didapat jumlah skor 129,25 dengan rata-rata $83,39 \%$, sedangkan pada siklus II didapat jumlah skor 135,2 dengan rata-rata 87,25\%, terdapat 
peningkatan 3,86\%. Hal ini dapat dibuktikan juga pada peserta didik bahwa motivasinya meningkat, mempunyai konsep diri positif, pemahaman perguruan tinggi dan dunia kerja meningkat yang menjadikan kemampuan pemilihan karir meningkat. Sehingga penelitian ini dapat disimpulkan bahwa hipotesis diterima yakni adanya peningkatan kemampuan pengambilan keputusan karir melalui layanan informasi berbasis WhatsApp Group pada siswa SMK Negeri 1 Kalasan tahun pelajaran 2020-2021.

Berdasarkan saran dan masukan dari kolaborator pada hasil wawancara dan hasil observasi pelaksanaan layanan, maka penerapan model layanan informasi berbasis WhatsApp Group dalam upaya peningkatan kemampuan pemilihan karir di SMK Negeri 1 Kalasan akan dilaksanakan pada kelas XI, agar supaya peserta didik mempunyai kesempatan lebih matang dalam pengambilan keputusan karir dan informasi yang didapatkan dapat sesuai kebutuhan. Selain itu WhatsApp Group juga diterapkan pada layanan informasi-informasi yang lainnya. Dengan materi yang lebih difokuskan pada tema layanan yang akan diberikan, sehingga tujuan layanan lebih terpusat dan hasilnya lebih optimal. Layanan informasi berbasis WhatsApp Group juga dapat diterapkan sebagai layanan informasi tambahan, jika layanan informasi tatap muka atau langsung hasilnya belum maksimal.

\section{DAFTAR PUSTAKA}

Ahmad Nafi (2020), Pengembangan Model Layanan Informasi Karier Memanfaatkan Audiovisual Untuk Meningkatkan Kematangan Karier Siswa, Institut Agama Islam Negeri Salatiga, DOI : https://doi.org/10.26877/empati.v7i1.5631.

Arif Mustofa (2020), Analisis Penggunaan WhatsApp Sebagai Media Bahasa Arab di Era Industri 4.0, http://dx.doi.org/10.29240/jba.v4i2.1805.

Gunawan Y (1987), Pengantar Bimbingan dan Konseling, Jakarta : Gramedia Pustaka Utama.

Indah Wijaya Antasari \& Wiwik Novianti (2019), Pemanfaatan Grup Whatsapp Pada Komunitas Kelas Menulis Pustakawan (Kmp), UNSOED, Volume 7 Nomor 1, Juni 2019 ISSN: 2303-0194.

Kasbolah, Kasihani (1993), Teaching-Learning Strategy I, Malang : IKIP Malang.

Munandar, A. S. (2004). Psikologi Industri dan Organisasi. Jakarta: Universitas IndonesiaPress.

Nararya Rahadyan Budiyono (2016), Pengembangan Model Layanan Informasi Studi Lanjut Berbasis Multimedia Interaktif Untuk Meningkatkan Wawasan Dunia Perguruan Tinggi Siswa Sma Kota Yogyakarta, “Tesis”, Program Pascasarjana Program Studi Bimbingan Dan Konseling Universitas Negeri Semarang.

Nur Lia Pangestika (2018), Pengaruh Pemanfaatan Media Sosial WhatsApp Gruop Terhadap Penyebaran Informasi Pembelajaran di SMK Negeri 5 Depok, Skripsi, Jurusan Pendidikan Ilmu Pengetahuan Sosial, Fak Ilmu Tarbiyah dan Keguruan, UIN Syarif Hidayatullah, Jakarta.

Prayitno \& Amti, E. (2008). Dasar-Dasar Bimbingan dan Konseling, Rineka Cipta, Jakarta.

Sugiyono.(2009). Metode Penelitian Pendidikan, Pendekatan Kuantitatif, Kualitatif da R \& D. Bandung: Alfabeta.

Tarsudi (2016), Tindakan Media Layanan Informasi Bidang Karir Berbasis Web Untuk Siswa Kelas XI SMA Negeri 1 Ambarawa Tahun 2015/2016, Skripsi, Universitas Negeri Semarang.

Yusuf Syamsu. LN. (2011). Psikologi Perkembangan Anak Dan Remaja. Bandung: PT. Remaja Rosdakarya. 